\begin{tabular}{l|l|l|l} 
Case Reports $\boldsymbol{h}$ & $\begin{array}{l}\text { Case Rep Dermatol 2010;2:27-31 } \\
\text { D01: } 10.1159 / 000296271\end{array}$ & Published online: March 27, 2010 & $\begin{array}{l}\odot 2010 \text { S. Karger AG, Basel } \\
\text { ISSN 1662-6567 } \\
\text { www.karger.com/cde }\end{array}$ \\
\hline
\end{tabular}

\title{
Alopecia Areata Associated with Localized Vitiligo
}

\author{
Shankarling D. Kuchabal ${ }^{\mathrm{a}}$ D.S. Kuchabal ${ }^{\mathrm{b}}$ \\ ${ }^{\mathrm{a}}$ Dermatologist and Cutaneous Surgeon and ${ }^{\mathrm{b}} \mathrm{Chief}$ Dermatologist, Dr. Kuchabal \\ Hospital, Belgaum, India
}

\section{Key Words}

Alopecia areata $\cdot$ Localized vitiligo $\cdot$ Autoimmune disorders

\begin{abstract}
Alopecia areata is a common cause of noncicatricial alopecia that occurs in a patchy, confluent or diffuse pattern. It may occur as a single, self-limiting episode or may recur at varying intervals over many years. The association of alopecia areata with localized vitiligo has not been reported. The association of alopecia areata with localized vitiligo in the same patient is documented here; it is the first of its kind.
\end{abstract}

\section{Introduction}

Alopecia areata manifests as loss of hair on a hairy part of the skin, such as the scalp, beard, mustache, etc., which may be patchy, confluent or diffuse in pattern. It may occur as a single, self-limiting episode or may recur at varying intervals over many years [1]. Strong direct and indirect evidence supports an autoimmune etiology for alopecia areata. The origin of the disease process is not fully understood; however, there are indications for a $\mathrm{T}$ cell-mediated autoimmune process directed against an unknown autoantigen of the hair follicle. T lymphocytes that have been shown to be oligoclonal and autoreactive are predominantly present in the peribulbous inflammatory infiltrate [2]. Alopecia areata frequently occurs in association with other autoimmune disorders such as generalized vitiligo, lichen planus, morphea, lichen sclerosus et atrophicus, pemphigus foliaceus, atopic dermatitis, Hashimoto's thyroiditis, hypothyroidism, endemic goiter, Addison's disease, pernicious anemia, lupus erythematosus, diabetes mellitus, Down's syndrome and others $[3,4]$.

\section{Case Report}

A 15-year-old girl presented with loss of hair since 4 years. She complained of loss of hair over the frontal area of the scalp and over the posterior aspect of the scalp above the neck region. She complained of depigmented lesions since 7 months on the right and left leg. 


\begin{tabular}{l|l|l|l} 
Case Reports $\boldsymbol{h}$ (Case Rep Dermatol 2010;2:27-31 & Published online: March 27, 2010 & $\begin{array}{l}\text { ○ 2010 S. Karger AG, Basel } \\
\text { ISSN 1662-6567 } \\
\text { www.karger.com/cde }\end{array}$ \\
$\begin{array}{ll}\text { Dol: } \underline{10.1159 / 000296271} \\
\end{array}$ & & \\
\hline
\end{tabular}

On examination, loss of hair was seen over the frontal region of the scalp (fig. 1) and over the posterior region of the scalp above the neck region. Two depigmented lesions were seen on the right leg (fig. 2) and one on the left leg (fig. 2). There was no evidence of atopic dermatitis, neurodermatitis, seborrheic dermatitis, verrucae, furunculosis, lichen planus and lichen sclerosus et atrophicus. Systemic diseases like thyroid disorders, anemia, diabetes, allergic rhinitis and bronchial asthma, hypertension and ulcerative colitis were not observed in the patient.

\section{Discussion}

Various theories are suggested for the etiology of alopecia areata and vitiligo. The association of alopecia areata with seemingly unrelated autoimmune disorders has led to an intense search for immune derangements [5]. In vitiligo, an autoimmune hypothesis is suggested by its clinical association with a number of disorders considered to be autoimmune [5]. Vitiligo seems to occur about 4 times more often in patients with alopecia areata than in the general population [4]. Alopecia areata accounts for around $2 \%$ of new dermatological outpatient attendances in Britain and the United States.

Among the factors that appear to be implicated in etiopathogenesis are the genetic constitution of the patient, atopic state, nonspecific immune and organ-specific autoimmune reactions and possibly emotional stress [6]. Alopecia areata has been considered as an autoimmune disease due to an aberrant $\mathrm{T}$ cell response against hair follicle self antigens [7]. This autoimmune etiology has also been proposed on the basis of its association with autoimmune diseases, the presence of autoantibodies and various underlying immunologic abnormalities in the affected sites of these patients. Lesions in alopecia areata do not form and resolve in the usual sense; however, as evident by its chronicity and high rate of recurrence, the disease represents a continuous reactivity of the pilar units. The capacity of hair to react in clinically recognized patterns as alopecia areata is probably inherited, although the mode of inheritance, penetrance and expressivity of the genes must be highly variable [4]. Alopecia areata may begin as early as the first month of life $[7,8]$ or as late as in the late seventies [4]. Family history of alopecia areata was not present in our patient.

Atopy has been reported to occur with an increased frequency in patients with alopecia areata $[4,9]$. The atopic type in Ikeda's classification of alopecia areata comprised $10 \%$ of 1,989 patients [10]. Similarly, $11 \%$ of 736 patients with alopecia areata studied by Muller and Winkelmann [4] had concomitant asthma or atopic dermatitis. In our patient, there was no history of atopy. One of the main systemic associations of autoimmune diseases is with thyroid abnormalities. The incidence of thyroid disease has varied from $8-28 \%$ in patients with alopecia areata [11]. Lewinski et al. [12] also confirmed the frequent coexistence of alopecia areata and thyroid abnormalities. Conversely, in 1994, Puavilai et al. [13] estimated that the prevalence of thyroid disease is relatively low (7.2\%), and patients with thyroid disease were not statistically different from patients with alopecia areata and the control group. Thyroid abnormalities were not seen in our patient. In one study, there was a high association of alopecia areata and familial generalized vitiligo [14]. The association of alopecia areata with localized vitiligo has not been reported.

Vitiligo can be separated into segmental and nonsegmental types [15]. In nonsegmental vitiligo, there is usually symmetric distribution of lesions and new patches may appear throughout the patient's life. It may be either generalized or localized. In generalized, nonsegmental vitiligo, there is usually widespread distribution of depigmented patches. Vitiligo which is so extensive that few normally pigmented patches remain is known as vitiligo universalis. Acrofacial vitiligo skin involvement is limited to 


\begin{tabular}{c|l|l|l}
$\begin{array}{c}\text { Case Reports } h \\
\text { Denmofology }\end{array}$ & $\begin{array}{l}\text { Case Rep Dermatol 2010;2:27-31 } \\
\text { D01: } 10.1159 / 000296271\end{array}$ & Published online: March 27, 2010 & $\begin{array}{l}\text { O 2010 S. Karger AG, Basel } \\
\text { ISSN 1662-6567 } \\
\text { www.karger.com/cde }\end{array}$ \\
\hline
\end{tabular}

the distal digits and periorificial facial areas. Focal vitiligo lesions are limited in quantity and location and have a nondermatomal distribution. Focal vitiligo may develop into generalized vitiligo or may follow an early-stabilizing clinical course [16]. Segmental vitiligo has important differences in etiology, prevalence of associated illnesses and therapy compared to other forms of vitiligo. It usually has unilateral involvement and a dermatomal distribution. Segmental vitiligo is known for its early onset and rapid spread. Without treatment, lesions are typically persistent throughout life, but stop developing within 2 years of onset. Childhood vitiligo, in one survey, consisted primarily of typical generalized, nonsegmental vitiligo (78\%), with focal vitiligo (14.4\%) and segmental vitiligo (4.6\%) being far less prevalent [17].

\section{Acknowledgement}

We would like to thank Howard I. Maibach, MD, professor at the Department of Dermatology, University of California, 90 Medical Center Way Surge 110, Box 0989, San Francisco, CA 94143-0989 (USA) for his help in preparation of this article.

Fig. 1. Shows loss of hair over the frontal region of the scalp.

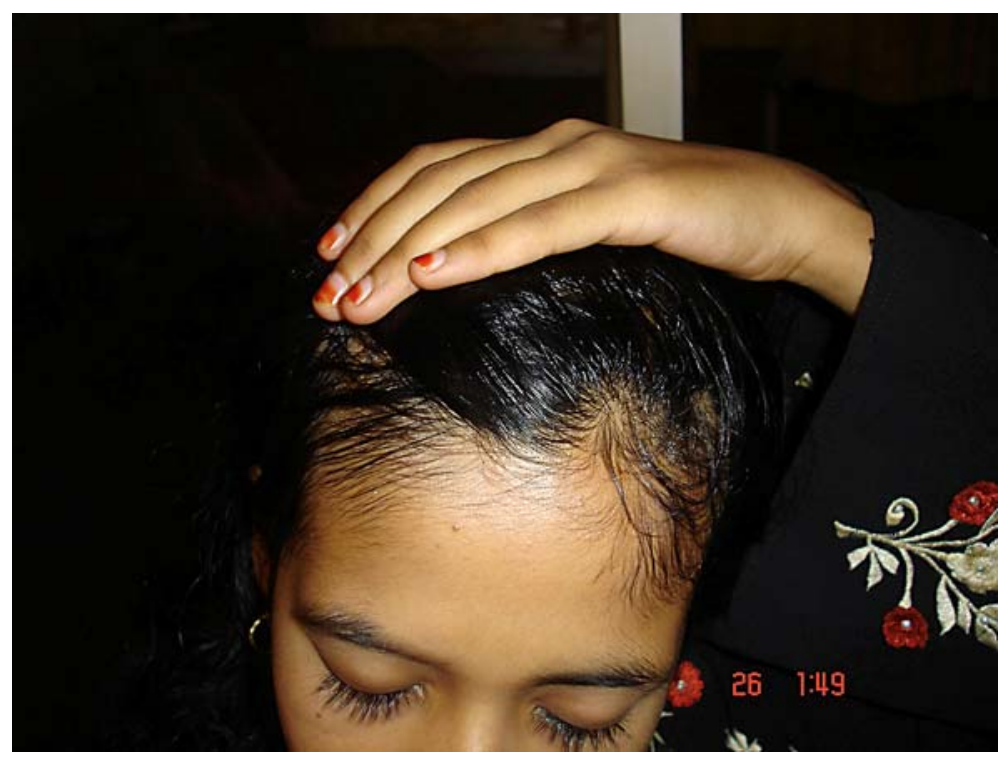


Fig. 2. Shows two depigmented lesions seen on the right leg and one on the left leg.

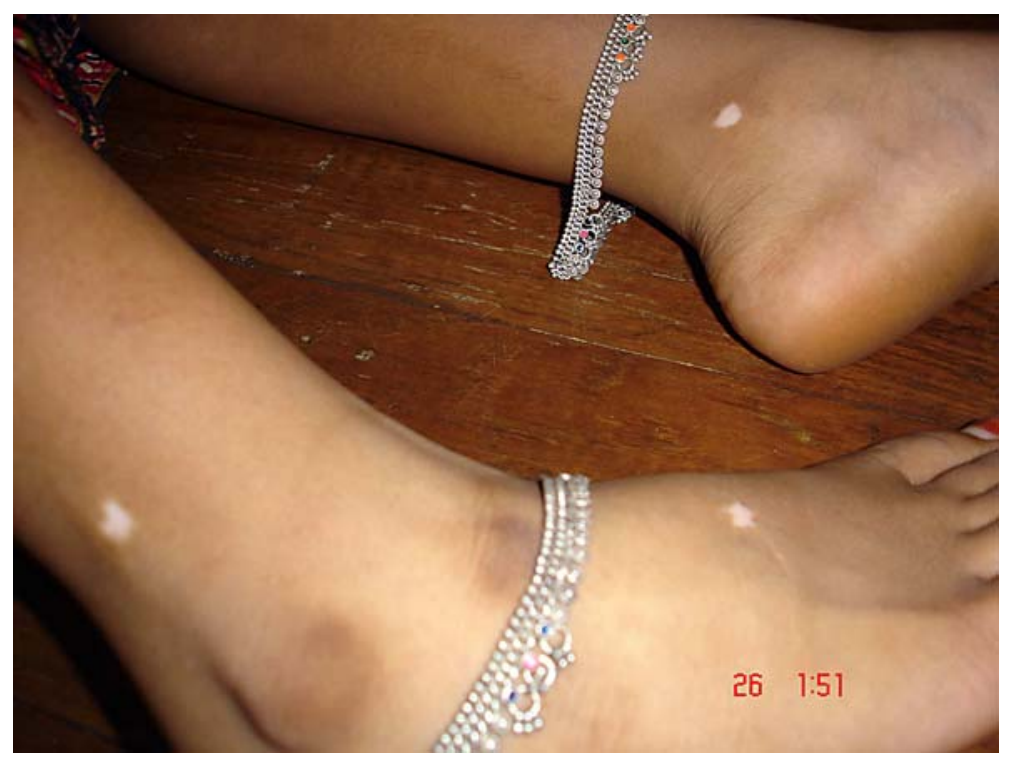




\section{References}

1 Thomas EA, Kadyan RS: Alopecia areata and autoimmunity: a clinical study. Indian J Dermatol 2008;53:70-74.

2 Hordinsky M, Ericson M: Autoimmunity: alopecia areata. J Investig Dermatol Symp Proc 2004;9:73-78.

- 3 Brenner R: Coincidences of alopecia areata, vitiligo, onychodystrophy, localized scleroderma and lichen planus. Dermatologica 1979;159:356-358.

-4 Muller SA, Winkelmann RK: Alopecia areata. An evaluation of 736 patients. Arch Dermatol 1963;88:290-297.

5 Bleehan SS, Ebling FJG: Disorders of skin colour; in Rook A, Wilkinson DS, et al. (eds): Textbook of Dermatology, 5th ed. Oxford, Blackwell Scientific Publications, pp 1561-1622.

6 Manzoor S, Masood C: Alopecia areata in Kashmir: a study of 200 patients. Indian J Dermatol Venereol Leprol 2001;67:324-325.

-7 Tobin DJ, Orentreich N, Fenton DA, Bystryn JC: Antibodies to hair follicles in alopecia areata. J Invest Dermatol 1994;102:721-724.

8 Nanda A, Al-Fouzan AS, Al-Hasawi F: Alopecia areata in children: a clinical profile. Pediatr Dermatol 2002;19:482-485.

-9 Freinkel RK, Freinkel N: Hair growth and alopecia in hypothyroidism. Arch Dermatol 1972;106:349.

10 Ikeda T: A new classification of alopecia areata. Dermatologica 1965;131:421-446.

-11 Vinod K, Sharma VK, Goutan D, Bhushan K: Profile of alopecia areata in Northern India. Int J Dermatol 1996;35:22-27.

-12 Lewinski A, Broniarczyk-Dyla G, Sewerynek E, Zerek-Melen G, Szkudlinski M: Abnormalities in structure and function of the thyroid gland in patients with alopecia areata. J Am Acad Dermatol 1990;23:768-769.

13 Puavilai S, Puavilai G, Charuwichitratana S, Sakuntabhai A, Sriprachya-Anunt S: Prevalence of thyroid diseases in patients with alopecia areata. Int J Dermatol 1994;33:632-633.

14 Zhang Z, Xu SX, Zhang FY, Yin XY, Yang S, Xiao FL, Du WH, Wang JF, Lv YM, Tang HY, Zhang XJ: The analysis of genetics and associated autoimmune diseases in Chinese vitiligo patients. Arch Dermatol Res 2009;30:167-173.

15 Ortonne JP, Bahdoran P, Fitzpatrick TB, Mosher DB, Hori Y: Hypomelanoses and hypermelanoses; in Freedberg IM, Eisen AZ, Wolff K, Austen KF, Goldsmith LA (eds): Fitzpatrick's Dermatology in General Medicine, 6th ed. New York, McGraw-Hill Professional, 2003, pp 839-847.

16 el-Mofty AM, el-Mofty M: Vitiligo: a symptom complex. Int J Dermatol 1980;19:237-244.

17 Handa H, Dogra S: Epidemiology of childhood vitiligo: a study of 625 patients from North India. Ped Dermatol 2003;20:107-110. 